\title{
N-terminal sequence analysis of human placental protein 14, purified in high yield from decidual cytosol
}

\author{
O. M. R. Westwood*, M. G. Chapman*, N. Totty†, R. Philp†, \\ A. E. Bolton $\ddagger$ and N. R. Lazarus§ \\ * Department of Obstetrics \& Gynaecology, Guy's Hospital, London SE1 9RT, U.K.; †Ludwig \\ Institute, Imperial Cancer Research Fund, London WC2 3PX,U.K.; ${ }_{\dagger}$ Department of Biology, City \\ of Sheffield Polytechnic, Sheffield S1 IWB, U.K.; and \$Rayne Institute, King's College Medical \\ School, London SE5 8RX, U.K.
}

\begin{abstract}
Summary. Human placental protein 14 (PP14) has been purified in high yield from first trimester decidual cytosol. High-performance liquid chromatography on anion exchange, gel filtration and reverse-phase chromatography were used. The protein obtained is approximately $97 \%$ pure with an overall recovery of about $50 \%$ from the original tissue extract. The first 24 amino acids of the $\mathrm{N}$-terminal were found to be MetAsp-Ile-Pro-Gln-Thr-Lys-Gln-Asp-Leu-Glu-Leu-Pro-Lys-Leu-Ala-Gly-Thr-Glu-HisGlu-Met-Ala-Met. PP14 has been characterized in this study to be a dimeric glycoprotein of $M_{\mathrm{r}} 60000$, with homologous subunits having an $M_{\mathrm{r}}$ of 28000 .
\end{abstract}

Keywords: human; PP14; decidual cytosol; h.p.l.c. techniques

\section{Introduction}

Human placental protein 14 (PP14) was first isolated from soluble extracts of term placenta. It is a glycoprotein of about $17.5 \%$ carbohydrate, exhibiting $\alpha_{1} \alpha_{2}$-electrophoretic mobility, with a pI of 4.5 (Bohn et al., 1982). The development of a radioimmunoassay for PP14 (Bolton et al., 1983) allowed detection in the peripheral blood of pregnant and non-pregnant females, amniotic fluid, placenta and endometrium, and high concentrations were found in first trimester decidua. Endometrial and decidual culture studies have demonstrated that these tissues secrete PP14 (Julkunen et al., 1986a). So far, PP14 in males has only been detected by RIA in the seminal plasma (Bolton et al., 1986). Several groups have independently isolated PP14 and have reported variations in its molecular weight, $\mathrm{pI}$ and whether PP14 is a monomeric or a dimeric protein. In addition, the described purification procedures, using various starting tissues, involve many steps, with consequent loss of material and possible effects on the molecular characteristics of the protein (Petrunin et al., 1978; Joshi et al., 1980a; Sutcliffe et al., 1980; Bohn et al., 1982; Bell, 1986b; Huhtala et al., 1987).

A 3-step method is described for the purification of PP14 from decidual cytosol by highperformance liquid chromatography, which overcomes the deficiencies described above.

\section{Materials and Methods}

Preparation of decidual cytosols. Decidual tissues, by permission of the ethical committee, were obtained from patients undergoing first trimester termination at Guy's Hospital, London. By microscopic control $(\times 10)$, decidua was separated from the placental and fetal tissues, washed in $0.9 \%(\mathrm{w} / \mathrm{v}) \mathrm{NaCl}$ to remove excess blood, then stored at $-20^{\circ} \mathrm{C}$. Decidual cytosol was prepared by macerating the thawed tissue with a McIlwan histological tissue chopper, 
and suspending in chilled $0.01 \mathrm{M}-\mathrm{Tris}-\mathrm{HCl} \mathrm{pH} 7.2$ buffer at a concentration of $500 \mathrm{mg}$ wet weight of tissue per ml of buffer. Homogenates were centrifuged at $80000 \mathrm{~g}$ at $4^{\circ} \mathrm{C}$ for $60 \mathrm{~min}$ and supernatants were stored as $\mathrm{I}-\mathrm{ml}$ samples at $-20^{\circ} \mathrm{C}$.

Quantitation and detection of PP14. Fractions positive for PP14 were quantified utilizing radioimmunoassay (Bolton et al., 1983), using purified PP14 (Lot no. 120/134) and antiserum (Lot no. 201ZA), obtained from Behringwerke AG (Marburg, FRG). PP14 was iodinated by the chloramine T method (Greenwood et al., 1963), and subsequently purified by affinity chromatography using concavalin A-Sepharose (Pharmacia, Milton Keynes, U.K.). A $30 \%$ binding of labelled PPI 4 was obtained by diluting the antiserum 1:6000. Protein elution profiles were identified by u.v. detection at $280 \mathrm{~nm}$. When tested against amino acid analysis, the RIA gave $90 \%$ of the calculated value for PP14, with respect to quantitation.

Total solubilized protein determinations. These were performed at each step of the purification schedule, using the colorimetric method described by Bradford (1976). Bovine serum albumin was used as the reference standard protein.

One-dimensional SDS-PAGE. A 12-track SDS discontinuous gel slab was used with a $10 \%$ acrylamide (containing $0.27 \%$ bis-acrylamide) resolving gel pH 8.9 , and a $3.5 \%$ acrylamide $(0.1 \%$ bis-acrylamide $)$ stacking gel pH 6.8 , as described by Laemmli (1970). To test for purity, samples of fractions positive for PP14, detected by RIA, and molecular weight markers were prepared by mixing with an equal volume of $0.125 \mathrm{M}$-Tris- $\mathrm{HCl} \mathrm{pH} 6.8$ buffer containing $5 \%$ (w/v) SDS, $20 \%(\mathrm{v} / \mathrm{v})$ glycerol, $10 \%(\mathrm{v} / \mathrm{v}) 2$-mercaptoethanol, and $0.002 \%(\mathrm{w} / \mathrm{v})$ bromophenol blue. Gels were fixed in $20 \%$ ethanol and $3.5 \%$ perchloric acid in water, then stained with $0.04 \%(\mathrm{w} / \mathrm{v})$ Coomassie Blue G (Sigma, Poole, U.K.) in fixing solution. Molecular weight markers used to calibrate the gel were phosphorylase (97 400), bovine serum albumin (66000), ovalbumin (44000), carbonic anhydrase (29000) and lactalbumin (14000) (Sigma, Poole, U.K.).

One-dimensional native PAGE. This utilized the same buffer systems and acrylamide concentrations as above, but omitted the $10 \%$ SDS and $10 \%$ 2-mercaptoethanol, on a 12-track discontinuous gel slab. Native gels were stained with Coomassie Blue $\mathrm{G}$ under the same conditions as for SDS-PAGE.

Anion exchange chromatography. The TSK DEAE 5PW ultrapac column $(7.5 \times 75 \mathrm{~mm}$; LKB Bromma, Croydon, U.K.) was pre-equilibrated with $0.05 \mathrm{M}-\mathrm{Tris}-\mathrm{HCl} \mathrm{pH} \mathrm{7.2}$. Decidual cytosol was thawed and passed through a $0.02 \mu \mathrm{m}$ filter (Minisart NML, Sutton, U.K.) and $500 \mu \mathrm{l}$ sample were injected onto the column. A linear $0-0.6 \mathrm{M}$-sodium chloride gradient was applied at a flow rate of $0 \cdot 2 \mathrm{ml} / \mathrm{min}$ and $1-\mathrm{min}$ fractions were collected.

Gel filtration. A $600 \mu 1$ sample of the peak PP14-containing fractions from the DEAE SPW column were applied to a Suparose $12 \mathrm{HR}$ 10/30 column ( $\mathrm{V}=25 \mathrm{ml}$ : Pharmacia, Milton Keynes, U.K.). The column was previously equilibrated and subsequently eluted with $0.05 \mathrm{M}$-Tris- $\mathrm{HCl}$ containing $0.15 \mathrm{M}-\mathrm{NaCl} \mathrm{pH} 7.2$ at a flow rate $0.5 \mathrm{ml} / \mathrm{min}$ for $60 \mathrm{~min}$, and $0 \cdot 5-\mathrm{ml}$ fractions were collected.

Reverse-phase chromatography. A TSK ODS 120T $5 \mu \mathrm{m}$ ultrapac column $(4.6 \times 250 \mathrm{~mm}$; LKB Bromma $)$ was equilibrated with $30 \%(\mathrm{v} / \mathrm{v})$ acetonitrile in water containing $1 \%(\mathrm{v} / \mathrm{v})$ trifluoroacetic acid. PP14 peak fractions $(1 \mathrm{ml})$ from gel filtration were loaded and the proteins were eluted on a linear $30-80 \%(\mathrm{v} / \mathrm{v})$ acetonitrile gradient containing $1 \%(\mathrm{v} / \mathrm{v})$ trifluoroacetic acid. A flow rate of $1 \mathrm{ml} / \mathrm{min}$ was applied and $1-\mathrm{ml}$ fractions were collected.

Analysis of the amino acids of the N-terminal of PP14. Purified PP14 was reduced and alkylated with 4-vinyl pyridine as described by Fullmer (1984). The sample was desalted by elution on a Brownlee C 8 aquapore RP300 column $(2.1 \times 220 \mathrm{~mm}$, Anachem, Luton, U.K.), which had been equilibrated with distilled water containing $0.1 \%$ $(\mathrm{v} / \mathrm{v})$ trifluoroacetic acid. A linear gradient of $0-90 \%(\mathrm{v} / \mathrm{v})$ acetonitrile in water containing $0 \cdot 1 \%$ trifluoroacetic acid was applied at a flow rate of $0.2 \mathrm{ml} / \mathrm{min}$ for $70 \mathrm{~min}$, and $100-\mu \mathrm{f}$ fractions were collected.

The N-terminal chain sequence analysis of PP14 was performed using the Applied Biosystems 477A sequencing system (Hewick et al., 1981).

\section{Results}

Total solubilized protein and PP14 concentrations were estimated at each step of the isolation procedure and percentage recovery (yield) was calculated. One-dimensional SDS-PAGE analysis (Fig. 1) was performed on the PP14 peak fractions and total solubilized protein:PP14 ratios were calculated to assess purity (Table 1).

Protein elution profiles of each of the chromatographic steps as identified by u.v. detection at $280 \mathrm{~nm}$ and PP14 concentrations estimated by RIA are indicated in Fig. 2. PP14 was eluted from the DEAE 5PW column at about $0.25 \mathrm{M}-\mathrm{NaCl}$. Haemoglobin was a major contaminant of the decidual cytosol, most probably due to the vascularity of the starting material. When an elution buffer of $\mathrm{pH} 7 \cdot 2$, equivalent to the $\mathrm{pI}$ of haemoglobin was selected, haemoglobin passed through 


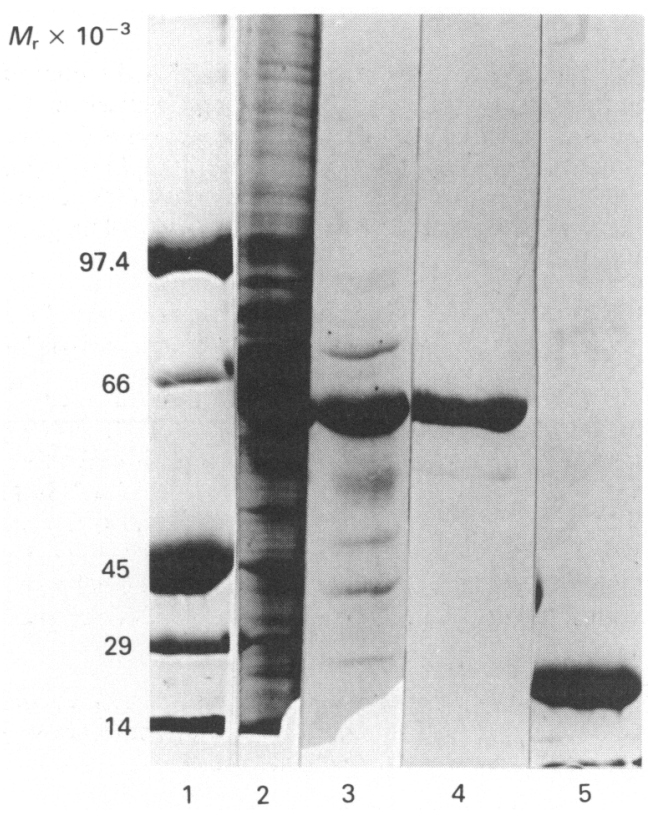

Fig. 1. One-dimensional SDS-PAGE of the peak fractions of the three chromatographic steps of the purification of PP14 from decidual cytosol. Peak fractions detected by RIA and u.v. at $280 \mathrm{~nm}$. Lane $1=$ molecular weight markers; Lane $2=$ decidual cytosol; Lane $3=$ anion exchange chromatography; Lane $4=$ gel filtration; Lane 5 = reverse-phase chromatography.

Table 1. Estimations of total solubilized protein (TSP), by the colorimetric method described by Bradford (1976), and PP14 concentrations, by RIA, performed on the crude decidual cytosol and at each of the three chromatographic steps of the purification schedule

\begin{tabular}{lrcccc}
\hline & $\begin{array}{c}\text { TSP } \\
(\mathrm{mg})\end{array}$ & $\begin{array}{c}\text { PP14 } \\
(\mu \mathrm{g})\end{array}$ & $\begin{array}{c}\text { TSP:PP14 } \\
\text { ratio }\end{array}$ & \% Yield & \% Purity* \\
\hline Decidual cytosol & 24.94 & 838.6 & $1: 0 \cdot 04$ & 100 & - \\
Step 1: anion exchange & 1.37 & $780 \cdot 3$ & $1: 0 \cdot 57$ & 93 & 57 \\
Step 2: gel filtration & $0 \cdot 61$ & 507.2 & $1: 0.83$ & 60 & 83 \\
Step 3: reverse-phase & 0.43 & $415 \cdot 9$ & $1: 0.97$ & 49 & 97 \\
\hline
\end{tabular}

${ }^{*}$ Assessed by the TSP:PP14 ratio and by one-dimensional SDS-PAGE.

the column with minimum retention. The molecular weights of PP14 and haemoglobin are similar ( 60000 and 64000 respectively). These proteins would be difficult to resolve by gel filtration. Elimination of haemoglobin at this initial stage simplified subsequent manipulations.

PP14 was eluted from the Suparose $12 \mathrm{HR} 10 / 30$ column at fraction $27(13.5 \mathrm{ml})$ and molecular weight markers were used as calibration standards. On reverse-phase (TSK ODS 120T), in which 

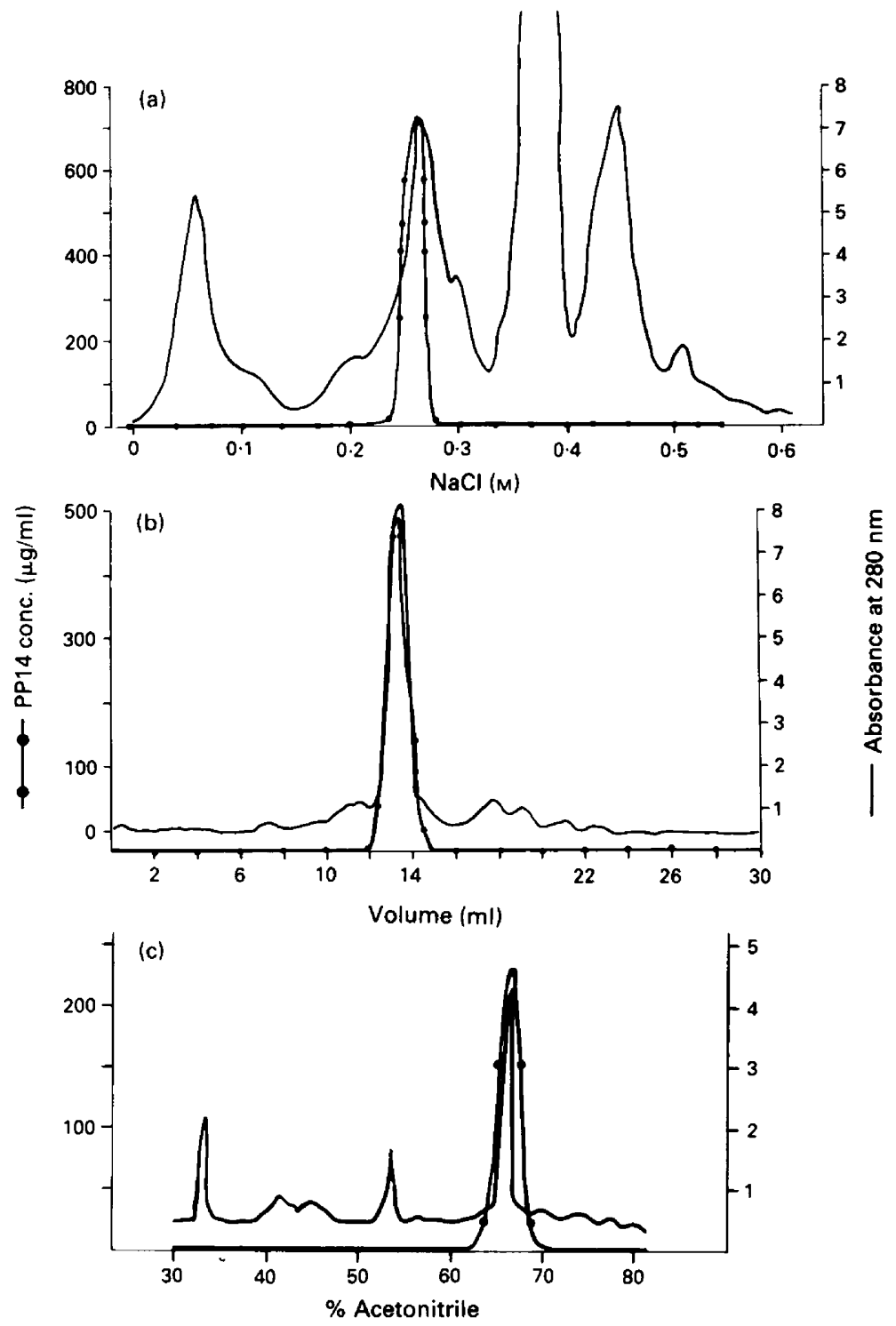

Fig. 2. Protein elution profiles of the three chromatographic steps in the purification of PP14 from decidual cytosol. (a) Step 1, anion exchange chromatography; (b) Step 2, gel filtration; (c) Step 3, reverse-phase chromatography.

elution is related to the hydrophobicity of the components fractionated, PP14 was eluted at about $70 \%$ acetonitrile, suggesting that PP14 has many hydrophobic residues.

Purified PP14, reduced and alkylated with 4-vinyl pyridine, was eluted from the C8 reversephase column at about $60 \%$ acetonitrile. The major peak was loaded on to the Applied Biosystems 477A sequenator. Figure 3 represents the elution profile from the $C 8$ reverse-phase column and the cyclic cleavage of the consecutive amino acid residues from the N-terminal of PP14. Analysis of the first 24 amino acids of the $\mathrm{N}$-terminal of PP14 revealed the sequence as:

$$
\text { M D I P Q T K Q D L E L P K L A G T E H E M A M }
$$

(see Fig. 4 for the coding of the amino acid sequence). 

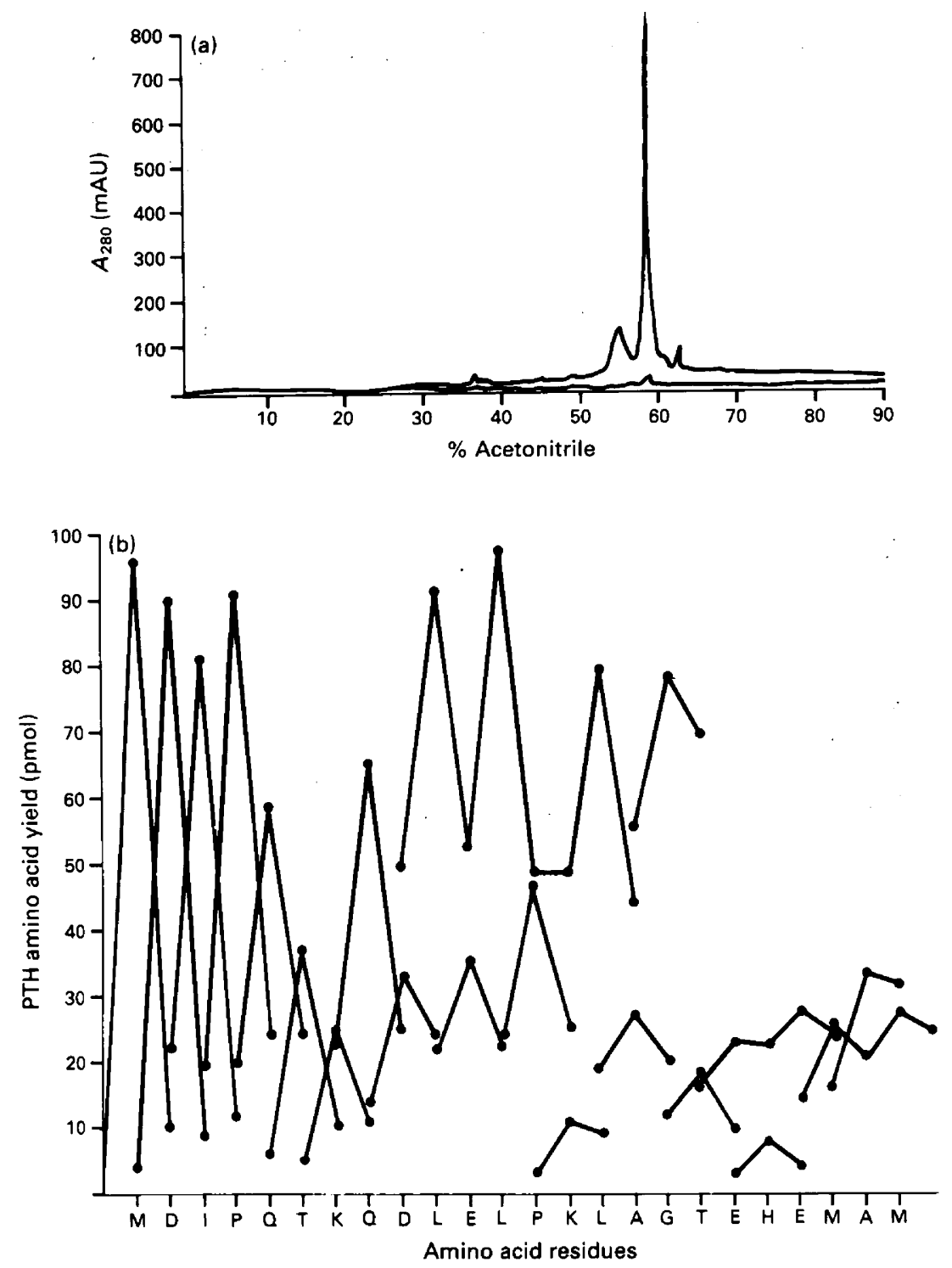

Fig. 3. Elution profiles of N-terminal amino acid analysis of PP14: (a) profile of PP14, treated with 4-vinyl pyridine, from the Brownlee $\mathrm{C} 8$ reverse-phase column, and (b) concentrations of the consecutive amino acid residues in their cyclic cleavage from the N-terminal of PP14 (see Fig. 4 for the key to amino acids).

The molecular weight of PP14 isolated from Step 1 was estimated by gel filtration and native PAGE and indicated an $M_{\mathrm{r}}$ of 60000 . When PP14 was further purified on gel filtration (Step 2), SDS PAGE gave an $M_{\mathrm{r}}$ of 60000 (Fig. 1, Lane 4). When the same material was eluted on reversephase chromatography with $70 \%$ acetonitrile and $1 \%$ trifluoroacetic acid, a single band corresponding to an $M_{\mathrm{r}}$ of 28000 was obtained under the reducing and non-reducing conditions of SDS-PAGE. This indicates that the subunits of PP14 are not held together by disulphide bonds, and dissociate in a hydrophobic environment. A single band also suggests homologous subunits, a finding confirmed by $\mathrm{N}$-terminal analysis in which only one set of sequence data was found. 


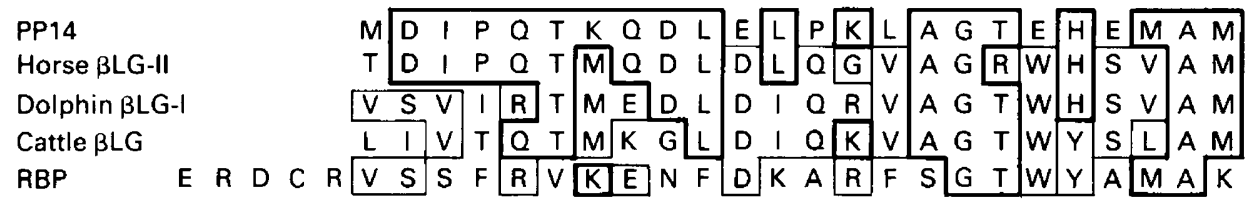

Fig. 4. A comparison of the $\mathrm{N}$-terminal sequence analysis of PP14 with horse, dolphin and cattle $\beta$-lactoglobulin ( $\beta \mathrm{LG}$ ) and human serum retinol-binding protein (RBP). Boxed residues marked with — indicate homology with PP14; boxed residues marked with — indicate homology with the $\beta$-lactoglobulins and RBP. $\mathrm{A}=$ alanine; $\mathrm{C}=$ cysteine; $\mathrm{D}=$ aspartic acid; $\mathrm{E}=$ glutamic acid; $\mathrm{F}=$ phenylalanine, $\mathrm{G}=$ glycine; $\mathrm{H}=$ histidine; $\mathrm{I}=$ isoleucine; $\mathrm{K}=$ lysine; $\mathrm{L}=$ leucine; $\mathrm{M}=$ methionine; $\mathrm{P}=$ proline; $\mathrm{Q}=$ glutamine; $\mathrm{R}=$ arginine; $\mathrm{T}=$ threonine; $\mathrm{V}=$ valine; $\mathrm{W}=$ tryptophan; $\mathrm{Y}=$ tyrosine.

\section{Discussion}

Several research groups have isolated proteins which subsequently have been shown to be similar and in some cases identical to PP14 by both immunological and physico-chemical analysis. Each group has ascribed a name to their protein, thereby producing a chaotic nomenclature. PP14 has been shown to be antigenically identical with chorionic $\alpha_{2}$-microglobulin (CAG-2), sometimes referred to as placenta-specific $\alpha_{2}$-microglobulin (PAMG-2). CAG-2/PAMG-2 was isolated from first trimester placenta and is reported to have a molecular weight of 25000 (Petrunin et al., 1978). This molecule probably represents the subunit of PP14, produced by their isolation procedure. In the absence of sequence data for CAG-2, it is possible that this protein could represent a polymorphic form of PP14. Joshi et al. (1980a, b, 1982) isolated progestagen-dependent endometrial protein (PEP) from human decidua of early pregnancy and studied its distribution in related tissues and fluids. Radioimmunological and immunodiffusion techniques have shown PEP to be immunologically indistinguishable from PP14 (Julkunen et al., 1986b). Alpha-uterine protein (AUP), also isolated from extracts of human decidua (Sutcliffe et al., 1980), exhibits serological identity with PEP. Both AUP and PEP are dimeric glycoproteins with an $M_{\mathrm{r}}$ of 50000 , subunit 25000 , and of 48000 , subunit 28000 , respectively (Sutcliffe et al., 1982), and are localized in the glandular and surface epithelium of the endometrium (Mazurkiewiecz et al., 1981). Like PP14 and PEP, pregnancy-associated endometrial $\alpha_{2}$-globulin $\left(\alpha_{2}\right.$-PEG) (Bell, 1985), is a dimeric glycoprotein which binds concavalin A-Sepharose with similar molecular weight estimations $\left(M_{\mathrm{r}} 56000\right.$, subunit 28000 ). Marginal differences in pI have been reported, PEP being 4.9, PP14 4.6, and $\alpha_{2}$-PEG 4.7 (average), due to the presence of multiple pI forms (Joshi et al., 1980b; Bohn et al., 1982; Bell, 1986a, b; Bell \& Patel, 1987). It has been agreed that PP14 and $\alpha_{2}$-PEG immunologically crossreact (Bell \& Bohn, 1986). These two molecules are probably identical or perhaps $\alpha_{2}$-PEG represents a polymorphic form of PP14.

The present studies were undertaken to purify PP14, define the molecular weight, some physicochemical properties, and initiate studies of its primary structure. PP14 has been prepared from decidual cytosol to about $97 \%$ purity by a three-stage system of anion exchange, gel filtration and reverse-phase chromatography. By gel filtration and native PAGE, we estimate the molecular weight of PP14 to be about 60000 . Under the reducing and non-reducing conditions of SDSPAGE, purified PP14 had an apparent $M_{\mathrm{r}}$ of 28000 , suggesting that PP14 is a dimeric protein. These results generally agree with those found for $\alpha_{2}$-PEG (Bell, 1986a, b) but differ from those of Julkunen et al. (1986a) who stated that PP14 was a single polypeptide chain. Bohn et al. (1982) suggested a molecular weight for PP14 of $42000-43000$, by the technique of ultracentrifugation. The physico-chemical properties of their protein preparation and ours are identical. We are unable to explain the differences in molecular weight estimations between the respective preparations. The variations may be attributed to the methodological differences in the respective purification schedules and the tissues used to extract and isolate this protein. 
Detection and quantitation of PP14 by RIA in the purification schedule utilized the PP14 antiserum and purified protein of Bohn et al. (1982). Immuno-electrophoretic techniques have identified that this PP14 antiserum (Lot No. 201ZA, Behringwerke AG, Marburg, FRG) exhibits specificity for placental protein 12 (PP12) and alpha-fetoprotein (AFP) (T. Fay, personal communication). The presence of PP12 and AFP in fractions positive for PP14, in the initial steps of the purification, could falsely elevate the PP14 values, thereby creating a negative bias with respect to the estimated yield. Parallelism of binding affinity with the PP14 antiserum was observed when our pure preparation of PP14 was serially diluted. Comparing quantitation of the RIA with amino acid analysis of PP14 purified in our schedule (monomeric PP14), the RIA gave about $90 \%$ of the calculated value for PP14. The $10 \%$ discrepancy may be explained by a methodology-associated bias. Therefore, it may be suggested that the PP14 antiserum recognizes a site on the monomer of PP14, and the RIA can precisely quantify both the monomeric and dimeric forms in terms of the real mass of the protein. Analysis of the first 18 amino acids of the $\mathrm{N}$-terminal has shown identity with the sequence data determined by Huhtala et al. (1987). Some diversity occurs between the two sets of data further along the polypeptide chain. This can probably be explained by genetic polymorphism. The following results suggest that PP14 is a dimeric protein with homologous subunits. Firstly, PP14 is eluted at an $M_{\mathrm{r}}$ of about 60000 by gel filtration, but of 28000 under the reducing and non-reducing conditions of SDS-PAGE. Secondly, PP14 was eluted as a single peak on the $\mathrm{C} 8$ reverse-phase column after treatment with 4 -vinyl pyridine. Finally, $\mathrm{N}$-terminal sequence analysis revealed only one set of sequence data.

Significant homology exists between PP14 and $\beta$-lactoglobulins of a number of species, including horse, dolphin and cattle, and human serum retinol-binding protein, if the first residues of PP14 and the three $\beta$-lactoglobulins are aligned with residue 6 of retinol-binding protein (Pervais \& Brew, 1985; Godovac-Zimmerman et al., 1985; see Fig. 4).

As far as the function of PP14 is concerned, reports are both inconclusive and varied. The findings of homology in sequence data of PP14 and the $\beta$-lactoglobulins has not assisted since the physiology of the $\beta$-lactoglobulins is also unclear (Pervais \& Brew, 1985). Binding studies attempting to show that PP14 is a retinol-binding protein are unconvincing (O. M. R. Westwood, unpublished observation). Bolton et al. (1987) have suggested an immunosuppressive function of PP14, purified by the techniques of anion exchange and gel filtration. Nomenclature still remains a problem, since the names suggested by the various groups are based on the tissue of origin rather than the structural or functional characteristics of the protein. With the first 24 amino acids of the Nterminal now characterized, we hope to undertake a structural analysis of both the protein and the gene.

We thank the Departments of Histopathology and Audio-visual aids for practical assistance; Dr G. S. Morris for technical advice; and Dr H. Bohn for the kind donation of PP14 reagents.

\section{References}

Bell, S.C. (1985) Immunochemical detection and characterization of pregnancy-associated endometrial $\alpha_{1}$ and $\alpha_{2}$-globulins secreted by the human endometrium and decidua. J. Reprod. Fert. 74, 261-270.

Bell, S.C. (1986a) Secretory endometrial and decidual proteins: studies and clinical significance of the maternally derived group of pregnancy associated serum proteins. Hum. Reprod. 1, 129-143.

Bell, S.C. (1986b) Purification of human secretory pregnancy-associated endometrial $\alpha_{2}$-globulin from the cytosol of first trimester pregnancy endometrium. Hum. Reprod. 1, 313-318.
Bell, S.C. \& Bohn, H. (1986) Immunochemical and biochemical relationship between secreted human pregnancy-associated endometrial $\alpha_{1}$ - and $\alpha_{2}$-globulins ( $\alpha_{1}-$ PEG and $\alpha_{2}-$ PEG) and the soluble placental proteins 12 and 14 (PPI2 and PP14). Placenta 7, 283-294.

Bell, S.C. \& Patel, S.R. (1987) Immunochemical detection, physicochemical characterization and levels of pregnancy-associated endometrial $\alpha_{2}$-globulin $\left(\alpha_{2}-\right.$ PEG) in the seminal plasma of men. J. Reprod. Fert. 80, 31-42.

Bohn, H., Kraus, W. \& Winkler, W. (1982) New soluble 
placental tissue proteins: their isolation, characterisation, localization, and quantification. Placenta 4, 67-81.

Bolton, A.E., Chapman, M.G., Stoker, R.G., Andrew, C.E., Wass, D. \& Bohn, H. (1983) The radioimmunoassay of human placental protein 14 (PP14). Clin. Chim. Acta 135, 283-291.

Bolton, A.E., Pinto-Furtado, L., Andrew, C.E. \& Chapman, M.G. (1986) Measurement of the pregnancy associated proteins, placental protein 14 and pregnancy associated plasma protein 14. Clin. Reprod. Fertil. 4, 233-240.

Bolton, A.E., Clough, K.J., Stoker, R.J., Pockley, A.G., Mowles, E.A., Westwood, O.M.R. \& Chapman, M.G. (1987) Identification of placental protein 14 as an immunosuppressive factor in human reproduction. Lancet i, 593-595.

Bradford, M.M. (1976) A rapid and sensitive method for the quantitation of microgram quantities of protein utilizing the principle of protein dye binding. Analyt. Biochem. 72, 248-254.

Fullmer, C.S. (1984) Identification of cystienecontaining peptides in protein digest by high performance liquid chromatography. Analyt. Biochem. 142, 336-339.

Godovac-Zimmerman, J., Conti, A., Liberatori, J. \& Braunitzer, G. (1985) The amino acid sequence of $\beta$-lactoglobulin II from horse colostrum (Equus caballus, Perissodactyla): $\beta$-Lactoglobulins are retinol-binding proteins. Biol. Chem. Hoppe-Seyler 366, 601-608.

Greenwood, F.C., Hunter, W.M. \& Glover, J.S. (1963) The preparation of ${ }^{13}$ I-labelled growth hormone of high specific activity. Biochem. J. 89, 114-123.

Hewick, R. E., Hunkapiller, M.W., Hood, L.E. \& Dreyer, W.J. (1981) A gas-liquid solid phase peptide and protein sequenator. J. biol. Chem. 256, $7990-7997$.

Huhtala, M.L., Seppälä, M., Narvanen, A., Palomäki, P., Julkunen, M. \& Bohn, H. (1987) Amino acid sequence homology between placental protein 14 and $\beta$ lactoglobulins from various species. Endocrinology 120, 2620-2622.
Joshi, S.G., Ebert, K.M. \& Swartz, D.P. (1980a) Detection and synthesis of a progestagen-dependent protein of the endometrium. J. Reprod. Fert. 59, 273-285.

Joshi, S.G., Ebert, K.M. \& Smith, R.A. (1980b) Properties of progestagen dependent protein of the endometrium. J. Reprod. Fert. 59, 287-296.

Joshi, S.G., Banks, J.F., Henriques, E.S., Makarrachi, A. \& Matties, G. (1982) Serum levels of progestagen associated endometrial protein during the menstrual cycle and pregnancy. J. clin. Endocr. Metab. 55, 642-648.

Julkunen, M., Koistinen, R., Sjöberg, J., Rutanen, E-M., Wahlstrom, T. \& Seppälä, M. (1986a) Secretory endometrium synthesizes placental protein 14 . Endocrinology 118, 1782-1786.

Julkunen, M., Raikar, R.S., Joshi, S.G., Bohn, H. \& Seppälä, M. (1986b) Placental protein 14 and progestagen associated endometrial protein are immunologically indistinguishable. Hum. Reprod. 1, 7-8.

Laemmli, U.K. (1970) Cleavage of structural proteins during the assembly of the head of bacteriophage T4. Nature, Lond. 227, 681-685.

Mazurkiewiecz, J.E., Banks, J.F. \& Joshi, S.G. (1981) Immunocytochemical localization of a progestagen dependent endometrial protein in the human decidua. J. clin. Endocr. Metab. 52, 1006-1008.

Pervais, S. \& Brew, K. (1985) Homology of $\beta$-lactoglobulin, human serum retinol binding protein, and protein HC. Science, N.Y. 228, 335-337.

Petrunin, D.D., Gynaznova, I.M., Petrunina, Yu.A. \& Tatarinov, Yu.S. (1978) Comparative immunochemical and physico-chemical characteristics of human chorionic $\alpha_{1}$ and $\alpha_{2}$-microglobulin. Bull. exp. Biol. Med. USSR 5, 658-661.

Sutcliffe, R.G., Bolton, A.E., Sharp, F., Nicholson, L.V.B., \& MacKinnon, R. (1980) Purification of human alpha uterine protein. J. Reprod. Fert. 58, 435-442.

Sutcliffe, R.G., Joshi, S.G., Patterson, W.F. \& Banks, J.F. (1982) Serological identity between alpha uterine protein and progestagen-dependent endometrial protein. J. Reprod. Fert. 65, 205-209.

Received 8 May 1987 